\title{
The Empowerment of Upstream Downstream Human Resources to Revitalise Tapioca Industry
}

\author{
${ }^{1}$ EVA BANOWATI, ${ }^{2}$ NGABIYANTO,${ }^{3}$ INDAH ANIS SYUKURILAH, \\ ${ }^{4}$ DANANG JUNIOR TRIMASUKMANA
}

1,2,4 Faculty of Social Science, Universitas Negeri Semarang, ${ }^{3}$ Faculty of Economics, Universitas Negeri Semarang
email : ${ }^{1}$ evabanowatigeografi@mail.unnes.ac.id; ${ }^{2}$ mass_abi@yahoo.com; ${ }^{3}$ indahanis@gmail.com; ${ }^{4}$ djtrimasukmana@gmail.com

\begin{abstract}
Pati Regency has the highest cassava productivity in Central Java, however tapioca industry still experiences difficulty in finding raw materials, moreover, cassava farmers have low income. The objectives of this research are 1) to investigate spatial distribution pattern of cassava and tapioca industry, 2) to review the supply of cassava to self-sufficiency oriented tapioca, and 3) to create model of integrated empowerment pilot plan received by upstream-downstream human resources. The research used Cluster Area sampling technique of cassava field and Simple Random Sampling in tapioca industry. The pilot plan model approved by the human resources was the qualified and ready-to-process cassava. Other than that, it could increase additional value of cassava products made by chip makers or for stabilizing the supply to the downstream sector as the raw material for tapioca industry. The acceleration of food self-sufficient realization must be supported by areal basic farming extensification with the acceleration of national scale cassava field of 9.300 ha.
\end{abstract}

Keywords: agro-industry, empowerment of human resources, tapioca.

\section{Introduction}

Farming paradigm changing that increasing production oriented to be sustainable farming forces the farming sectors do the production activities naturally (Zulvera, et al. 2014:149). Tapioca industry in Pati Regency is located nearby the location of cassava production which forms agroindustry site area to support food availability, to provide added value of cassava, to provide employment (employment creator). Build an integrated system involving human resources, cassava as agricultural products, science and technology tapioca industry, money and market information. Tapioca starch as raw material for food and non-food industries is also referred to as downstream agro-industry product. On a national scale, Indonesia as an agrarian country needs to transform towards agricultural-based industrialization, as the agricultural industry is an urgent sector capable of leading other sectors toward a more modern economy.

Given the growth of food and beverage industry in Indonesia made from tapioca raw materials increased by $8.19 \%$, influenced by the highest domestic market growth in Asean. Tapioca is processed into sweetener syrup (sweetener) reaching 600-700 tons / year (Supratiwi, 2014 in Krisnamurti, 2015) is required by various food industries, including confectionery, fruit canning, and thickening agents. In addition to food, tapioca is also used to meet the needs of the paper industry, batik, and plywood. Domestic tapioca flour production reaches 5 million tons per year, while the need per year is 7 million tons. The domestic tapioca starch industries prefer to overcome the shortage through imports due to the stable supply, lower prices, and better quality (Ministry of Agriculture, 2013, Ministry of Trade, 2013; Kusbini, 2015).

These conditions are influenced production cassava keep fell to 21,8 million tons accompanied by price decline in sweet cassava and price tapioca (Badan Pusat Statistik, 2016) further impact food the vulnerability of the population growth rate

Received: July 24, 2018, Revision: Agustus 20, 2018, Accepted: December 7, 2018

Print ISSN: 0215-8175; Online ISSN: 2303-2499. DOI: http://dx.doi.org/10.29313/mimbar.v34i2.3878.454-463

Accredited B based on the decree No.040/P/2014, valid on February, 18, 2014 until February, 18, 2019. Indexed by DOAJ, Sinta, IPI 
national $1,49 \%$ per year. Ignored law demand, because met by cassava imports run throughout the year without considering harvest cassava in Indonesia. Indonesia food bankruptcy of material cassava and tapioca. Based on Badan Pusat Statistik (2015, in aziliya, 2016) imports in January - August reached 4.193,59 tons for the low production. In contrast, about 4 to 7 years ago, cassava production from 2008 to 2011 increased, export volume in the form of dried cassava, tapioca, chip and other forms increased. The highest national cassava production was achieved in 2011 at 28 million tons, in rough calculations obtained by tapioca 9.8 million tons. According to Addict (2012) this figure was much higher than Thailand which produced 26 million tons. This condition put Indonesia into exporter of cassava.

Farmers sell cassava Porto land to middlemen (in local language called ditebas) in order to earn money instantly without having to provide permanent harvester and hauling laborers to transport (Banowati, et al., 2015). Tapioca factory can meet the needs of cassava from wholesalers (brokers) and brookers (brokers). The cassava market chain is very short, cajoled by Wijana et al. (2011) as the figure 1 .

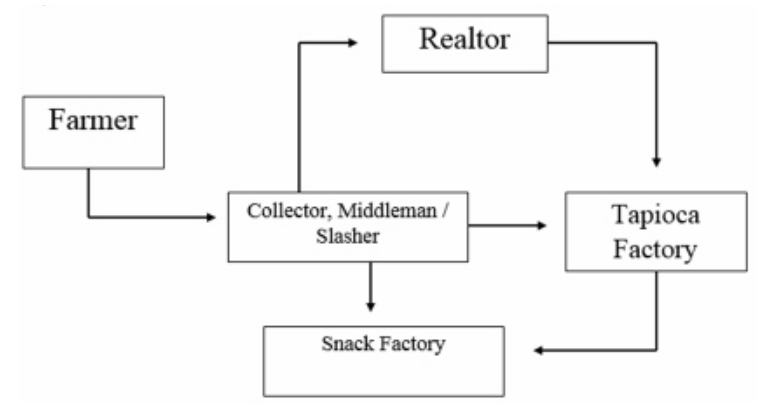

Figure 1. Cassava Marketing Chain

To overcome this problem, the Ministry of Agriculture launched a cultivation program of 9.300 hectares of cassava plant growth in 2015 that could potentially boost economic growth, reduce imports, optimize land use, and empower human resources (Ministry of Agriculture : 2013). Other than that, the policy of facilitating the establishment of tapioca industry encourages local producers to be interested in import substitution supported by local resources, namely: labor of farmers and industrial workers, and access to markets (Banowati, et al., 2017).

According to Aribowo's research (2014) in Pati Regency, that the emergence of tapioca industry backed with the terribly alarming agricultural conditions. Agriculture could no longer fulfill the needs of the community, tapioca starch industry was unable to replace the role of agriculture that was unable to meet the economic needs. Tapioca flour industry has developed rapidly due to its economic orientation, absorbing labor, and the need of advanced producers. Darwis et al. (2009) obtained income of cassava growers increased Rp. 35 per kilogram when selling in semiprocessed form, for example made chips (raw ceriping), or dried cassava.

Processing serves as a strategic activity to add value in the production chain and creating a competitive and comparative advantage. Strengthening the results of research Wijana, et al. (2011) that cultivation of cassava is feasible because farmers can benefit 67 percent of the total cost incurred. Thamrin, et al. (2013) analysis R / C Ratio with value 7,5> 1 farm worth to be developed.

Tapioca production in Pati Regency is a competitive sector supported by the availability of cassava comparative sector with Location Quotient (LQ) value of 0.96 , so that the existence is expected to be able to meet the needs of the region not for exports to other regions. However, the economic activity of this sector is able to serve both domestic and foreign markets (Ricardson 2001 in Muta'ali, 2015; Banowati, et al., 2017). Cassava productivity of Pati Regency is 41,673 ton/hectare which is higher than Central Java 25,965 ton/hectare; which is affected by the physical condition of existing land suitable for cassava crop.

Tapioca production process is very simple in both the process and time. Based on the theory of economic base, tapioca industry creates high added value, absorbs relatively large workforce, has high backward linkage or forward linkage, and has high growth rate (Tarigan, 2005 in Muta'ali, 2015).

The main problem of agriculture agroindustry in rural area must be handled in an integrated manner in whole chain of industrial agriculture system, from upstream to downstream (Darwis, 2009). Resolving the unsustainability of raw materials' supply, with the result that there won't be a gap between materials availability and production in agroindustrial activity called idle investment.

From these findings, it is necessary to increase the production of agroindustry area by: (1) mapping the spatial distribution of cassava land and spatial distribution of 
tapioca industry; (2) assessing cassava supply to tapioca food oriented self supporting industries, and ( 3 ) empowering cassava farmers in increasing land productivity and empowering labor tapioca industry.

\section{Research Method}

The survey research was conducted in Pati Regency at cassava production center and adjacent to center of tapioca industry. Research population of cassava area and tapioca industry location, and human resources of cassava farmers and tapioca industry workers. Determination of the number of area samples under the terms of the Geographic Information Agency (GIA). In the area of cassava $15.582 \mathrm{Ha}$ (Pati Regency in Figure, 2015) determined 30 sample points, and industrial samples from 4 point location of simple Random Sampling technique.

The primary data was obtained by observation, interpreting satellite imagery, the measurement of physical condition was done using geography tools. Then, to collect comprehensive data is done through Focus Group Discussion (FGD) on the problem and solution of cassava availability as tapioca industry supply. Focus Group Discussion (FGD) was conducted by involving relevant stakeholders: farmers, tapioca entrepreneurs, and associations. Secondary data was obtained from Badan Pusat Statistik. Spatial data collection was point data i.e industrial location. The absolute data was obtained from field results using GPS and then processed into maps through GIS (Geographic Information System) using ArcGis 10.1 software help.

The data analysis is based on a geographical approach focused on Nearest Neighbour Analysis, Moran analysis (in Muta'ali 2015) to find spatial distribution patterns represented by $T$ values) resulting in area features and their associations (Singarimbun and Effendi, 1995; Yunus, 2010). Descriptive quantitative analysis to find out the contribution of cassava supply to tapioca industry.

\section{Analysis}

Pati Regency is located in Central Java. The geographical position supports the development and the creation of the agricultural sector to improve the welfare of the population, the expansion of labor absorption, and the improvement of the economic status of the community through the development of agro-industrial areas. The agricultural sector plays an important role to meet the needs of the region itself as well as food staple inhabitants of Central Java. Supported by 237,912 people $(39 \%)$ of the population working in the agricultural sector as entrepreneurs, industrial workers and as family workers (Pati Regency in Figure, 2015).

Farmers are in a diametrically position, such as a community that felt the impact of climate change, due to its dependence on nature, as well as major stakeholders in the management of irrigated cassava (Suantapura, 2016:98).

The cassava area is 18,544 hectares (2014), but the harvest area is $96.37 \%$ $(17,871$ hectares). The total production of wet cassava with the skin of 744,746 Ton (BPS, 2015) consisted of bitter varieties of Cassesart (UJ-5) of $83.7 \%$ and sweet varieties of CMM $02048-6$ by $16.3 \%$ (Figure 2), but production decreased to 661,976 Ton (Pati Regency in Figure, 2016). Some causes are: the reluctance of farmers to grow cassava because the last two years (2014 and 2015) the selling price went down, the long cycle of cassava which is 10-12 months. Other issues from the farmers' side are: narrow land ownership, limited access to capital, and noninnovative technology. These conditions affect the tapioca industry has not / not running optimally caused by the unproductive quantity of cassava supply.

The need of food made from tapioca done with revitalization according to the potential of natural resources and the ability of human resources for the achievement of cassava production in food self-sufficiency.

\section{Spatial Distribution Pattern Analy- sis of Cassava Land and Tapioca Industry Location}

The administrative coverage of Pati Regency has varied forms that are influenced by the physiographic condition that stretches from the seaside (Java Sea) to produce marine and to volcanic forms. Type of soil Latosol, RedYellow, Mediterranean, the degree of acidity $(\mathrm{pH})$ above 6 structured crumbs, loose, and rich in organic matter. Rainfall and the distribution of rain that come down to form climate type C2, D2, and E1-E4 support cassava farming activities (Agricultural Service of Pati Regency, 2016, Banowati, et al., 2017). 
EVA BANOWATI, et al. The Empowerment of Upstream-Downstream Human Resources to Revitalise Tapioca ...

Interpretation of SPOT 6 satellite images of November 2014 is known that cassava land is located in the northern part of the physiology of the upper slopes to the lower slopes of Volkan Muria (83.7\%) covering Tlogowungu, Margoyoso, Cluwak, Gembong, Margorejo and Tayu districts. And $16.3 \%$ in the southern part on the northern slopes of Kendeng Mountains covering the District Sukolilo, Kayen, and Tambakromo. Look the figure 2 .
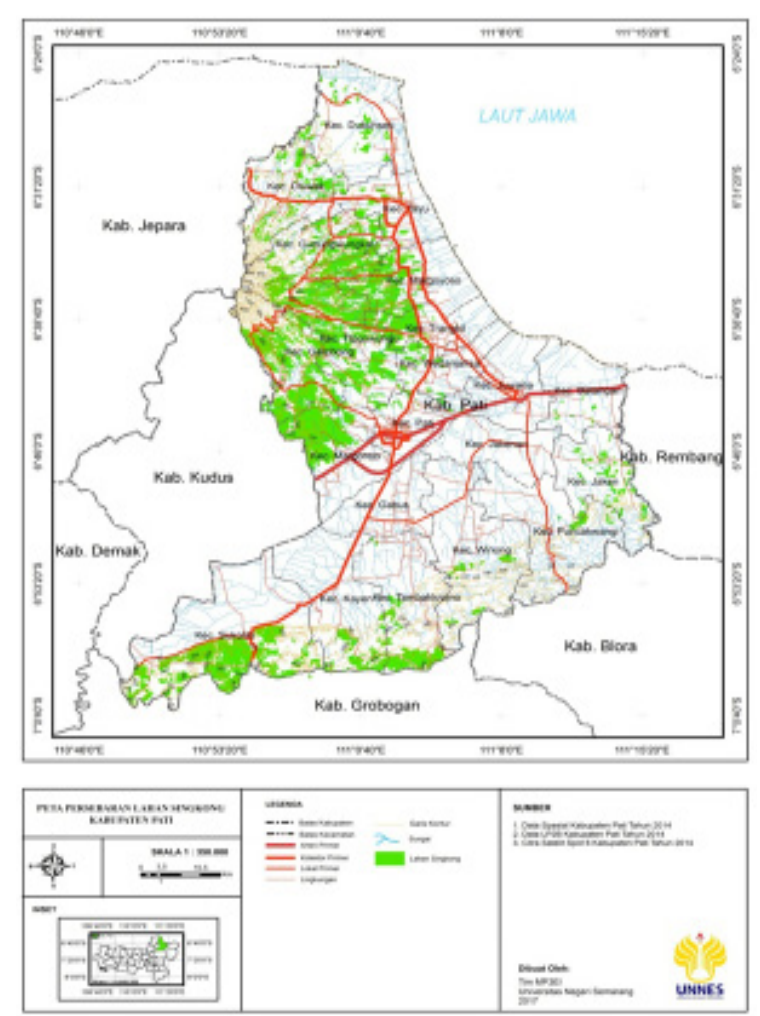

Source: Banowati, et al., 2016

Figure 2. Distribution of Cassava Land in Pati Regency

Calculation result of spatial distribution pattern analysis on Figure 2 is known The area spread index (Moran Index) influences to production and smooth supply, transportation in terms of cost, distance, and travel time. Look the figure 3 .

Total of join area $(L)$ Tlogowungu $=6$, meaning Tlogowungu Sub-district is bordered with 6 other districts. Value $x=4.283$, meaning to have cassava land area of 4,283 $\mathrm{Ha}$. The value of $\mathrm{L}$ Kecamatan Pati $=6$ means that transport of crops is easy, but the area of cassava is $16 \mathrm{Ha}$ (value $\mathrm{x}$ ). Based on the calculation results can be seen that the join area amounted to 63 . The calculation results to determine the spatial distribution pattern index used the formula:

Obtained a positive I value of 0.0038 , meaning the pattern of distribution of clustered cassava land, it facilitates transportation of cassava crops transport as tapioca industry supply.

\begin{tabular}{|c|c|c|c|c|c|c|}
\hline \multirow{2}{*}{ No. } & \multirow{2}{*}{ District } & \multirow{2}{*}{$\mathrm{t}$} & \multirow{2}{*}{$\mathrm{L}^{2}$} & \multicolumn{3}{|c|}{ Asea Value } \\
\hline & & & & $(x)$ & $(x-\bar{x})$ & $(x-\bar{x})^{2}$ \\
\hline 1 & Tlogowuagy & 6 & 36 & 4.283 & 3.47 & 11.675 .889 \\
\hline 2 & Germbcang & 2 & 4 & 3.276 & 2.410 & 5.808 .100 \\
\hline 3 & Clurvak & 3 & 9 & 2.427 & 1.561 & 2.436 .721 \\
\hline 4 & Guavagrnungeal & s & 25 & 1.400 & 934 & 285.156 \\
\hline s & Margogosso & 4 & 16 & 1.097 & 231 & 53.361 \\
\hline 6 & Margorejo & 4 & 16 & 1.638 & $m$ & 595984 \\
\hline 7 & Trangkil & 3 & 9 & 537 & .329 & 108.241 \\
\hline 8 & Dulubseti & 2 & 4 & 110 & .756 & 57.536 \\
\hline 9 & Tayv & 4 & 16 & 301 & .365 & 319.225 \\
\hline 10 & Sukolilo & 1 & 1 & 115 & .751 & 364.001 \\
\hline 11 & Jaken & 3 & 9 & 72 & .94 & 630.436 \\
\hline 12 & Winoagg & 4 & 16 & 51 & .815 & 664.225 \\
\hline 13 & Tambalromo & 3 & 9 & st & .815 & 664.225 \\
\hline 14 & Kayen & 3 & 9 & 63 & .803 & 644.809 \\
\hline 15 & Wedarjalks & 4 & 16 & 85 & .781 & 609961 \\
\hline 16 & Pati & 6 & 36 & 16 & .850 & 722500 \\
\hline 17 & Pucalkrangi & 3 & 9 & 33 & .813 & 660.969 \\
\hline 18 & Bstanga & 3 & 9 & 9 & .899 & 737.881 \\
\hline \multicolumn{2}{|c|}{ Total Join Area } & 63 & 249 & 15.582 & & 27.753 .220 \\
\hline & Averate & & & 866 & & \\
\hline
\end{tabular}

Figure 3. Tabel of Spatial Distribution Pattern of Cassava Land (Join Area Analysis).

Information:

$L=$ Number of join areas.

$\mathrm{x}=$ Cassava Land Area per District.

Sources : Badan Pusat Statistik, 2016 (Secondary Data Analysis, in Banowati, et al., 2017)

Referring to the theory of determining the location of Weber's industrial (1929, in Banowati, et al., 2017) which became the starting point of modern industrial thought. The analysis of geographical location determination has influence to the type of business and activity which take into account some spatial factors (space / place) to find optimal location and minimal cost of an industry supported by the availability of raw materials. Factory location should be closer to the source of raw materials for low cost (least cost location). Look the figure 4.

Especially the type of weight loss industry after passing through the production process, as well as tapioca industrial products lighter than raw materials (cassava).

The tapioca industry center of Pati Regency is located in Margoyoso Subdistrict, in this region, there are 269 units (Monography Margoyoso Sub District, 2016) spreaded in four villages: Sidomukti, Ngemplak Kidul, Tanjungrejo, and Waturoyo. The mapping of the spread of samples of industrial locations using GPS in the form of coordinate points can be seen in the figure 5 . 


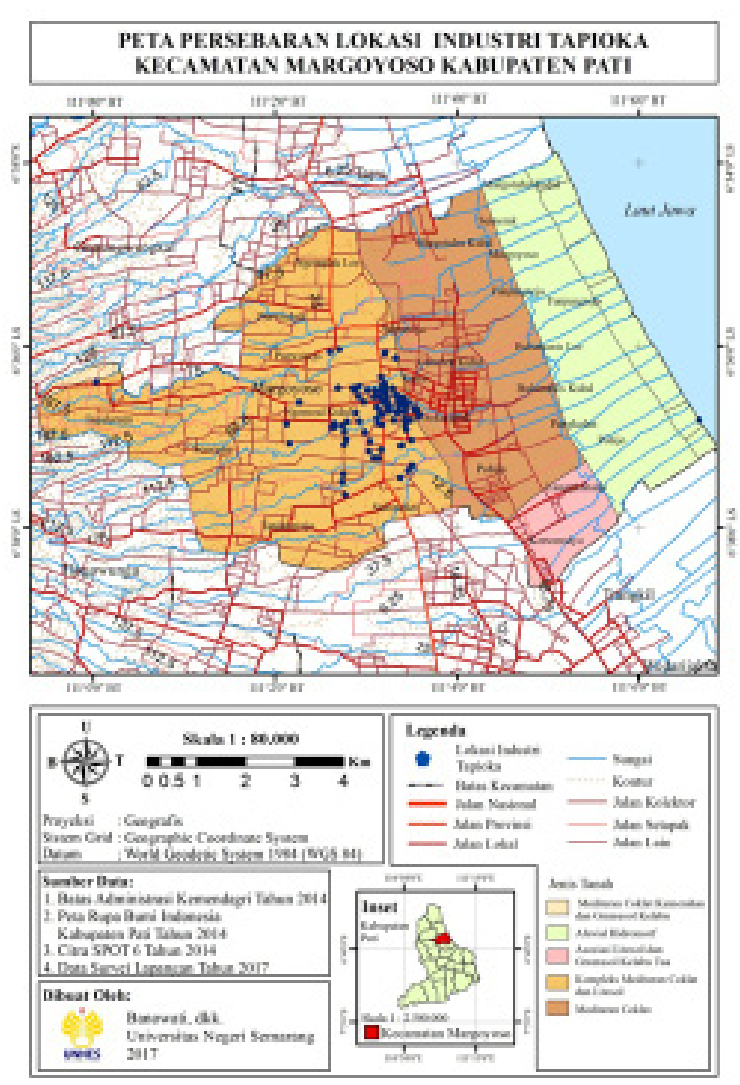

Figure 4. Factory location should be closer to the source of raw materials for low cost

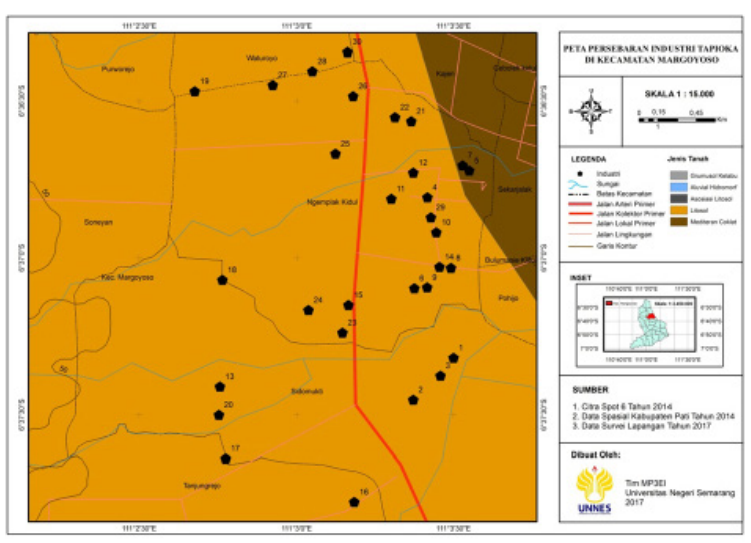

Figure 5. Agglomeration and Sample Distribution of Tapioca Industry

The pattern of the distribution of tapioca industry in Margoyoso sub-district is affected by the existence of raw material source, accessibility, culture of homophily specifically interaction between individuals with similar views, knowledge with strong empirical support (Rogers, 1983). The existence of raw material sources becomes one of the determinants of the existence of a secondary extractive industry.

Based on the primary data analysis
(2017), it was known pattern of random distribution (random pattern) indicated value $\mathrm{T} 0.849$ industrial location and position one location with other location not interrelated. At any location the industry is established in the Margoyoso sub-district to be profitable (least cost location) or prospective because it is easy to get cassava in groups (Figure 5). In line each industry is completely independent, can be seen in figure 6 .

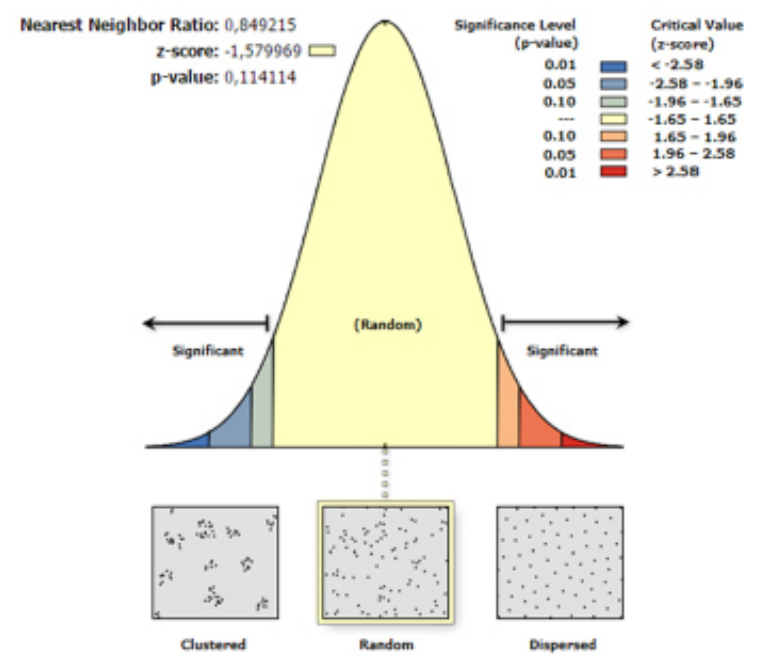

Sources: Banowati, et al., 2017

\section{Figure 6. Analysis of nearby neighbors using ArcGis 10.1 application}

Although, it is not denied by industry owners that the proximity of the location associated with the management of waste management into the river, it is done to minimize the water pollution. The nature of tapioca liquid waste contains vegetable organic substances that quickly decompose if left inundated in the open. Some of the rivers that become waste disposal sites include: Bango, Suwatu, and Pangkalan.

\section{Contribution of Cassava Supply to Needs in Tapioca Industry}

Pati Regency is the second biggest cassava producer in Central Java after Wonogiri Regency, the fact is maintained by 269 units of tapioca factories which are located in Margoyso District, employing 3.617 workers (Pati Regency in Figure, 2016). These factories produce cassava into tapioca for 6.8 tons per unit/ day or in other words, the total necessity of cassava is $1,829.2$ tons/ day which produce 640.22 tons/day. Total requirement of cassava for tapioca industry in 
Pati regency per year 667,658 ton (Banowati, et al., 2017).

Serial data of BPS lakes in Pati Regency of cassava production showed decreasing trend pattern due to harvest area decreased about 9, 27\% (year 2014), and 2015 decrease $14,95 \%(15,200$ hectare of harvest area) effect to cassava production to 661.976 ton Starch In Figures, 2016). Lack of cassava is overcome by bringing in from outside the region.

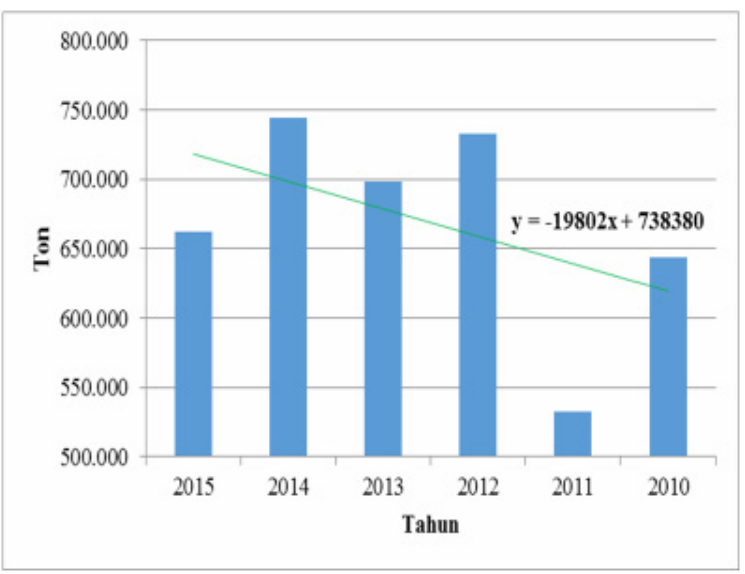

Source: Pati Regency in Figure, 2016 in Banowati, et al., 2017

\section{Figure 7. Diagram of Trend of Cassava Production in Pati Regency.}

Analysis of contribution of cassava production of area to supply of raw material source used calculation (Rokhmah, 2013), that is:

$\mathrm{KB}$ pas $=(\mathrm{Bd} / \mathrm{Btot}) \times 100 \%$

KB pas : Contribution of cassava production to supply

$\mathrm{Bd}$ : Supply of cassava from farmers in Pati Regency

Btot Raw materials needed by the industry

Cassava Harvest Area $=15.200 \mathrm{Ha}(2015)$.

Cassava Productivity $=41,673$ tons/hectare/ harvesting cycle

Total production of cassava $=15.200 \times 41,673$

$=633.429,6$ tons $/$ year

a. Variety of Cassesart (UJ-5) $83,7 \% \times$ $633.429,6=530.180,5752$ tons/ year

b. Varieties of CMM $02048-6$ is $16,3 \% \mathrm{x}$ $633.429,6$ tons $=103.249,0248$ tons/ year

Cassava demands (raw materials)

$=6,8$ tons/ day /unit

$=6,8 \times 269=1.829,2$ tons $/$ day

$=1.829,2 \times 365$ days $=667.658$ tons $/$ year

The contribution from local farmers to the demands of 269 units of tapioca industry of Pati Regency in 2015 can be described in a simple measurement as follows:

Tapioca industry in Pati Regency receives $20.59 \%$ of the supply from other areas, including Kudus, Rembang, Blora, Banjarnegara, and East Java Province. The supply of cassava from local farmers has been declining since 2014 due to the effect of farmers' attitude on land and delaying harvest time, the decrease of starch yield decreases the price of cassava in market down to $44.6 \%$. Tapioca industry is not producing optimally, but tapioca import until June more than 1 million ton/year done by Ministry of Trade (BPS, 2016). The domestic tapioca starch industries prefer imported tapioca starch for cheaper prices, better quality, and a continuous supply of certainty (Ministry of Industry, 2016). On the other hand, the Ministry of Agriculture has data on the production of local cassava farmers that is more than enough to meet the local market. On a national scale, the cause of other imports is not due to lack of production, according to Hendriadi (2016) cassava products not all of them have quality standards Hazard Analysis Critical Control Point Specification or HACCP. This problem builds a causal relationship required simultaneous integrative solutions from upstream to downstream to break the chain of food shortages.

The phenomenon of food shortage made from tapioca is reflected in the decrease of tapioca national production. Analysis of food consumption made from tapioca in 2015 amounted to $0.034 \mathrm{~kg} /$ capita/ year, whereas the previous year was $0.052 \mathrm{~kg} /$ capita/year. The availability per capita in 2011 was 721 $\mathrm{kg} /$ year, while in 2014 it was $7.24 \mathrm{~kg} /$ year or down more than $99 \%$ compared to 2011 or the average growth rate decreased $-7.58 \%$ (The Ministry of Agriculture, 2015), can be seen in figure 8.

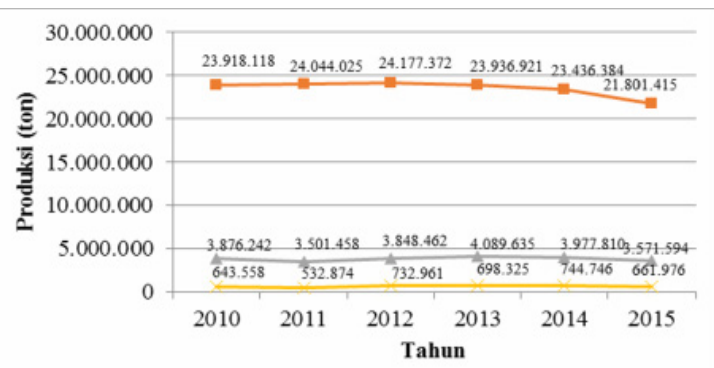

Sources: Badan Pusat Statistik, 2016 in Banowati, et al., 2017

Figure 8. Diagram of National Cassava Proction in 2010 - 2015 
Looking at the data in Figure 7, the highest national cassava production in 2012 and the next year tends to decline. Along with tapioca production of Central Java Province. Different phenomenon compared to Pati Regency production stability, although production decrease in 2015 effect from decreasing price of cassava on the market. The contribution of cassava from Pati Regency to the availability of food is grouped into 2 levels: provincial and national, it is known that the revocation of tapioca industry has the potential to sufficiently increase in demand for food supported by the quality of human resources in effective and efficient natural resource management by utilizing appropriate technology determine how much productivity through empowerment.

\section{Empowerment of Upstream Down- stream Human Resources to In- crease Regional Production}

The transformation from agrarian to industry known as agro-industry requires breakthroughs or leapfrogs to overcome food problems and limited employment opportunities in Indonesia caused by population growth. Agro-industry activities always require agricultural raw materials. This transformation in Pati Regency is supported by $30.72 \%$ farmers as upstream human resource and downstream human resources of $16.32 \%$ processing labor force (BPS of Pati Regency, 2016). The existence of tapioca industry in rural areas is able to absorb the labor of $8 \%$ of productive age group (BPS, 2016) and bring positive change to the improvement of society economic condition. Projected to process natural resources by increasing cassava and tapioca production with upstream - downstream human resource empowerment program in harvest and postharvest handling.

The average of cultivated land is 1.86 hectares/person, the average productivity of Daplang, Margona or Adira varieties is 21,96 tons per hectare (2013), but in 2015 Cassesart (UJ-5) the productivity increased to 41,67 tons/hectare (figure 9 ).

The efforts to overcome food selfsufficiency is optimized through agricultural intensification, as this step affects the quantity of tapioca products. Planting of Cassesart variety (UJ-5) at depth of $\pm 5 \mathrm{~cm}$, planting distance $9 \times 9 \mathrm{~cm}$ with calculation of one hectare of planted cassava plant
11,200 cuttings/tree, if one tree can produce $5 \mathrm{~kg}$ of cassava then yield 56 tons/hectare. The cassava area of Pati Regency is 15,582 hectares, the harvest is predicted to reach 872,592 tons per year (9-12 months) or increase $30.69 \%$ (204,934 tons). The yield of this variety is about $35 \%$, the skin is thin so it is easy in the process of processing, simply washed and unnecessary peeled.

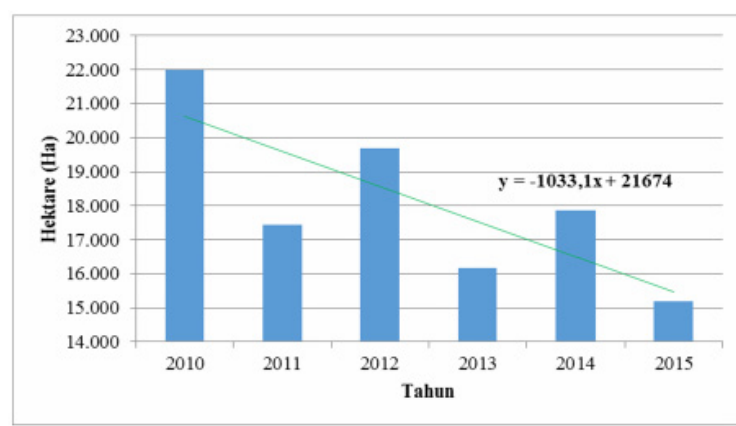

Sources: Badan Pusat Statistik, 2016 in Banowati, et al., 2017

\section{Figure 9. Diagram of Trend Area of Cassava Land of Pati Regency}

The empowerment scheme in this research is intensification oriented and postharvest management was visualized as in figure 10 .

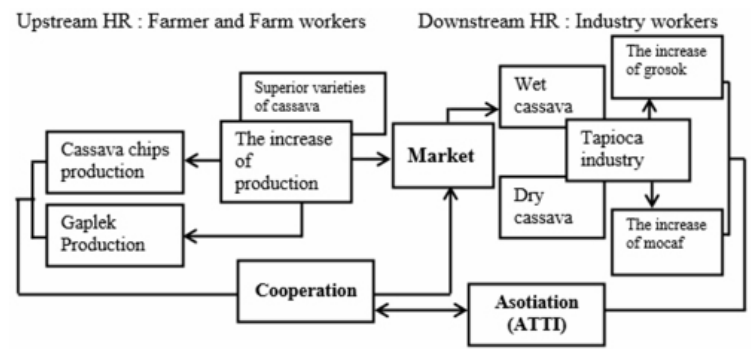

Sources: Banowati, et al., 2017

Figure 10. Empowerment Activity of Upstream-Downstream Human Resources

Upstream human resource empowerment has adopted thinking of Soemarno (2011, in Banowati, et al., 2017) which become subject is cassava farmer facilitated to form Kelompok Petani Singkong $(K P S)$ or Cassava Farmers Group (CFG) to facilitate service of member agribusiness effort such as determining harvesting season, and marketing. In the future, a sovereign institution is established as a sub-system in revitalizing based industries by establishing synergistic networking through mediation of agro-industry communication forums (Forka) in order to process innovation, transfer, 
technology adoption and market information quickly to group members. Besides, it can increase the added value of cassava products made by chipmakers or dried cassava for stability of supply to downstream sector that is tapioca industry, and easy in storage.

Empowerment of human resources downstream, in this study include: employers industrial owners and labor. The tapioca industry per unit has a labor force around 10-15 persons in a single cycle of production process consisting of pickled cutters, washing, grinding-precipitation, and drying. Cassesart (UJ-5) cassava varieties are thin-skinned so no skin peeling is required. Ability to process per unit of industry average 47.5 Ton cassava/ week yielded tapioca flour 19,3 Ton / week, yield about $40,6 \%$. The main obstacle of the industry is the scarcity of cassava supply, as well as the unbearable weather (rainy season) inhibits the drying. The action taken by industrial entrepreneurs is to produce tapioca gross grains, wet, and clumped (figure 11a and figure $11 \mathrm{~b}$ ).
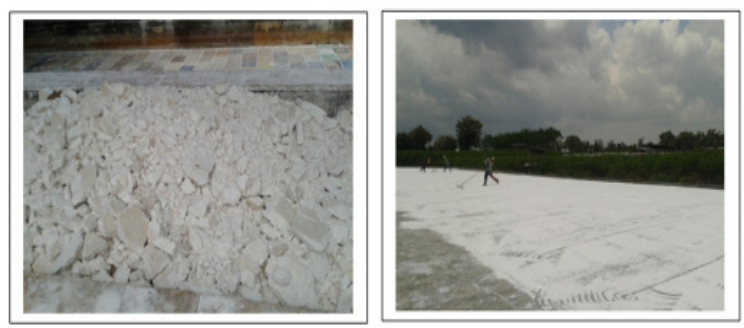

Figure 11a. Wet Krosok without drying, and $11 \mathrm{~b}$. Tapioca Drying Process

Tapioca grosok is the result of marinating flour after deposition without drying. The grosok bought by collectors for Rp. 3000 / $\mathrm{Kg}$, then further processed into dried tapioca which is worth Rp. 7,000 / Kg. (Banowati, et al., 2017).

In this condition, empowerment activities to accommodate the United Nations (1956, in Tampubolon, 2001, Banowati, 2011) are called stimulating the community to realize that it has problems, that is related to habits, in fact they do not feel that they have problems that need to be solved. FGD results followed by cassava farmers, industrial owners and workers of tapioca industry as an act of integration of empowerment in overcoming this problem is a pilot plan that is accommodated from the opinion of Wijana et al. (2009) best alternative that can be done is to process cassava into cassava as raw material of tapioca industry, got tapioca medium quality (AA) that is with degree of white 92 (Wijana, et al., 2006). The success of empowerment is affected by the accuracy in performing actions according to the characteristics of the target and as judgments of increasing purchasing power, continuity of food sufficiency, minimizing imports, achieving the acceleration of food self-sufficiency, and awakening community savings. In line with the policy of developing cassava crop aims to increase the income of farmers and make a larger contribution in the formation of GRDP (Badan Pusat Statistik, 2013).

In addition, intensification development of cassava production has been applied in annual practical by FAO. FAO (Howeler, 2013) in 2010 has started the program as "Save and Grow", which has an environmental approach in processing the natural resources. In the research, the program has helped about half a billion owners and processors of cassava production such as in Africa, Asia, Latin America, and the Caribbean Islands in cultivating cassava plants intensively. It is quite practical to minimize the use of inorganic fertilizers to protect soil fertility, optimize and manage time for planting and harvesting, and use biological control agents to control the development of plant pests and diseases. Accordingly, according to FAO, the continuity of cassava production will not only be more productive and profitable but also sustainability in the development of existing resources for the future.

\section{Conclusions}

The existence of tapioca industry in Pati Regency adjacent to the location of cassava producers to form the site of the agro-industrial area supports the availability of food. Established an integrated system involving human resources, cassava as agricultural products, science and technology of tapioca industry, money and market information accelerate and strengthen economic development in accordance with its superiority and strategic potential. So that farmers become prosperous, tapioca production as food in the country increased, reducing urbanization rate, and the availability of upstream-quality human resources. Starting from the ease of trying and opening new land. The 9,300 cassava garden growth acceleration program needs to be accompanied by improving the quality 
and competitiveness of human resources of farmers, and the tapioca industry work begins with the making of land needs map (land extension = extensification) and cassava quantity (intensification).

\section{References}

Addict. (2012). Ironis Indonesia menjadi Importir singkong Terbesar. Artikel https:// metrotvnews.com. (Uploaded October, $17^{\text {th }} 2012$, Downloaded June, $14^{\text {th }} 2016$ ).

Aribowo, Nofita Fahrodin. (2014). Industri Tepung Tapioka dan Pengaruh Sosial Ekonomi Masayarakat Desa Ngemplak Kidul Margoyoso Kabupaten Pati Tahun 1990 - 2005. Skripsi. Semarang: Universitas Negeri Semarang.

Aziliya, Dara. (2016). Produksi Ubi kayu Ditargetkan Capai 27 Juta Ton. Webpaper Bisnis Indonesia. 21 April 2016, (Downloaded July, 27th 2017).

Banowati, Eva. (2011). Pembangunan Sumber Daya Hutan Berbasis Masyarakat Di Kawasan Muria- Kabupaten Pati. Disertasi. Yogyakarta: Fakultas Geografi Universitas Gadjah Mada.

Banowati, Eva et al. (2015). Land Use Under Stand (PLDT) Model Development to Poverty Reduction and Realisation of Food Security at Pati Regency, Research of Strategic National Department of Research and Education, Jakarta.

Banowati, Eva., and Satya Budi Nugraha. (2016). Land Utilization Pattern in the Indonesian Forest: Cassava Cultivation in an Agroforestal System. http://dx.doi. org/10.5772/intechopen.76928

Banowati, Eva et al. (2017). Revitalisasi Industri Tapioka Terintegrasi Pemberdayaan SDM Hulu-Hilir Untuk Realisasi Swasembada Pangan. Laporan Penelitian MP3EI. Semarang: LP2M UNNES.

Banowati, Eva et al. (2017). Revitalization Model of Tapioca Industry Through Environmental Awareness Reinforcement For Minimizing Water Body Contamination. Article. ICMSE 2017.

Badan Pusat Statistik. (2015). Pati Regency in Figure. Pati: Badan Pusat Statisktik.

Badan Pusat Statistik. (2016). Produksi Ubi Kayu Menurut Provinsi (ton), 1993-2015.

Darwis, Valeriana et al. (2009). Analisa Usahatani dan Pemasaran Ubi Kayu serta Teknologi Pengolahan Tapioka Di Kabupaten Pati Propinsi Jawa Tengah. Seminar Nasional Peningkatan Daya Saing Agribisnis Berorientasi Kesejahteraan
Petani 4 Oktober 2009. Bogor: Pusat Analisis Sosial Ekonomi dan Kebijakan Pertanian Badan Penelitian dan Pengembangan Pertanian Departemen Pertanian.

Department of Agriculture of Pati Regency. (2016). Pati Regency Profile. Official website of Pati Regency. available at: https://www.patikab.go.id (accessed 17 May 2017).

Hendriadi. (2016). Produk singkong belum semuanya memiliki standar kualitas Hazard Analysis Critical Control Point Specification (HACCP).

Howeler, Reinhardt, NeBambi Lutaladio, and Graeme Thomas. (2013). Save and Grow : Cassava, A guide to sustainable production intensification. Roma, Italia : FAO Plant Production and Protection Division.

Kementrian Perindustrian, (2016). Impor Tapioka Harus Dikurangi. Jakarta: Dirjen Industri Agro.

Krisnamurti, Bayu. (2015). International Workshop on Cassava (IWoC). An Effort of Increasing Cassava Production and the Food Processing Industry Development. Malang: Fakultas Pertanian Universitas Brawijaya Malang.

Kusbini, Benny. (2015). RI Impor Singkong Vietnam Rp 14 M Diluar Garam. Online Article. (Uploaded September, 23 ${ }^{\text {rd }}$ 2015, Downlaoded March, $\left.5^{\text {th }} 2016\right)$.

Muta'ali, Lutfi. (2015). Teknik Analisis Regional Untuk Perencanaan Wilayah, Tata Ruang, dan Lingkungan. Yogyakarta: Badan Penerbit Fakultas Geografi Universitas Gadjah Mada.

Pati Regency in Figure. (2015). Luas Lahan Bukan Sawah dan Bukan Pertanian di Kabupaten Pati.

Pati Regency in Figure. (2016). Luas Lahan Bukan Sawah dan Bukan Pertanian di Kabupaten Pati.

Rogers, Everett M. (1983). Diffusion of Innovations : Third Edition. New York: The Free Press.

Singarimbun, M, and Effendi, S. (1995). Metode Penelitian Survei, Cetakan kedua, Jakarta: LP3ES.

Suantapura, Siska Rasiska. (2016). Perception, Mitigation and Adaptation Strategies of Irrigated Paddy Farmer Community to Face Climate Change. Journal of MIMBAR, Vol.32, No.1, June 2016 : 97-106

Tampubolon, Mangatas, (2001). Pendidikan, Pola Pemberdayaan Penduduk, dan Pemberdayaan Penduduk Dalam Pembangunan Sesuai Tuntutan Otonomi 
Daerah, dalam Jurnal Pendidikan dan Kebudayaan, Edisi November Th.VII. No.032. Jakarta: Balitbang.

Thamrin, Muhammad., Ainul Mardhiyah, dan Samsul Efendi Marpaung. (2013). 'Analisis Usahatani Ubi Kayu (Manihot Utilisima)'. Jurnal Agrium Vol. 18 No.1. Medan: Fakultas Pertanian UMSU.

The Ministry of Agriculture of Republic Indonesia. (2013). Analisis Kebijakan Impor Komoditas Food Additives And Ingredients Dalam Engurangi Defisit Neraca Perdagangan. Jakarta: Pusat Kebijakan Perdagangan Luar Negeri Badan Pengkajian dan Pengembangan Kebijakan Perdagangan.

The Ministry of Agriculture of Republic Indonesia. (2015). Statistik Konsumsi Pangan. Pusat Data Dan Sistem Informasi Pertanian.

Wijana, S., U. Effendi, and E. Rahayu, (2006). Analisis Kelayakan Proses Produksi Tapioka dari Gaplek pada Skala Industri UKM. Jurnal Agritek, Vol. 14 (4): 963-968.
Wijana, S., I. Nurika and E. Habibah, (2009). Analisis Kelayakan Kualitas Tepung Tapioka Berbahan Baku Gaplek Dengan Proses Pemutihan Menggunakan Kaporit. Jurnal Teknologi Pertanian, Vol. 10 No 2 August 2009: 97-105

Wijana, Susinggih, Nurika Irnia, and Ika Ningsih. (2011). Analisis Kelayakan Teknis dan Finansial Produksi Tapioka Dari Bahan Baku Gaplek Pada Skala Industri Kecil Menengah (Studi Kasus Di Sentra Industri Tapioka Kabupaten Kediri, Jawa Timur). Jurnal Teknologi Pertanian. Vol. 12 No. 2 page 130-137. Malang: Jurusan Teknologi Industri Pertanian, Fakultas Teknologi Pertanian-Universitas Brawijaya.

Yunus, Hadi Sabari. (2010). Metode Penelitian Wilayah Kontemporer. Pustaka Pelajar, Yogyakarta.

Zulvera, et al. (2014). Faktor-Faktor yang Berhubungan dengan Keberdayaan Petani Sayuran Organik di Kabupaten Agam dan Tanah Datar, Provinsi Sumatera Barat. Journal of MIMBAR Vol.30, No.2, December 2014: 149-158. 